\title{
Efficacy of transbronchial biopsy in pulmonary vaculitides
}

\author{
A. Schnabel*, K. Holl-Ulrich**, K. Dalhoff+, M. Reuter++, W.L. Gross*
}

Efficacy of transbronchial biopsy in pulmonary vaculitides. A. Schnabel, K. Holl-Ulrich, K. Dalhoff, M. Reuter, W.L. Gross. OERS Journals Ltd 1997.

ABSTRACT: This study was performed to determine the value of transbronchial biopsy (TBB) in patients with antineutrophil cytoplasmic antibody (ANCA)-associated vasculitides and mild-to-moderate pulmonary involvement.

Included in the study were 19 patients with Wegener's granulomatosis (WG) and six patients with Churg-Strauss syndrome (CSS) with evidence of active pulmonary disease but without gross parenchymal lesions accessible by radiologically guided biopsy. All of the patients had undergone staging examinations which included TBB taken from peripheral lung tissue and from any focal tracheobronchial lesions. Any suspicious lesion in the upper respiratory tract was biopsied by an otolaryngologist and the number of positive biopsies was compared with that of TBB.

In the WG patients, only two out of 17 biopsies of alveolar tissue yielded histopathological findings supporting the diagnosis of WG. In five WG patients, ulcerative or exophytic airway lesions were found whose histopathologies were invariably positive. Otolaryngological examination revealed abnormal findings in 19 WG patients and biopsies from these sites yielded positive results in 13 instances. In CSS, TBB produced a diagnostically helpful histopathology in four of six cases and biopsies from the upper respiratory tract were positive in five out of six cases.

We conclude that transbronchial biopsies of alveolar tissue are seldom positive in Wegener's granulomatosis patients with mild-to-moderate pulmonary disease unless they are taken from grossly abnormal lung areas. Conversely, ulcerative, exophytic or stenotic tracheobronchial lesions had a high rate of positive findings. These results further suggest that the upper rather than the lower respiratory tract should be the biopsy site of first choice in Wegener's granulomatosis. In Churg-Strauss syndrome, the upper and lower respiratory tract seem to yield a roughly equal number of positive biopsies.

Eur Respir J, 1997; 10: 2738-2743.
*Poliklinik für Rheumatologie, Medizinische Universität Lübeck, Rheumaklinik Bad Bramstedt, **Institut für Pathologie, Medizinische Universität Lübeck, ${ }^{+}$Klinik für Innere Medizin II, Medizinische Universität Lübeck, ${ }^{++}$Klinik für Radiologische Diagnostik, Universität Kiel, Germany

Correspondence: A. Schnabel

Rheumaklinik Bad Bramstedt

Oskar-Alexander-Straße 26

D-24576 Bad Bramstedt

Germany

Keywords: Bronchoalveolar lavage

bronchoscopy

computed tomography

lung biopsy

vasculitis

Received: November 251996

Accepted after revision September 281997
Wegener's granulomatosis (WG), Churg-Strauss syndrome (CSS) and other small vessel vasculitides have been termed clinicopathological entities to highlight the fact that they require a combination of clinical and histopathological findings to be diagnosed with confidence [1]. Although testing for antineutrophil cytoplasmic antibodies (ANCA) has proved to be a valuable adjunct in supporting the diagnosis, most authors agree that serological findings cannot substitute for histopathology and that histological confirmation remains a mainstay of diagnosis [2].

Clinical and pathological series have shown that the respiratory tract is a preferable biopsy site in these disorders, and a high diagnostic yield of open lung biopsy has been established [1, 3-5]. However, because open lung biopsy is associated with appreciable morbidity and a small but definite rate of mortality, it is held to be justified only in the event of gross lesions, which are very likely to yield a definitive diagnosis. Transbronchial biopsy (TBB) is associated with fewer risks and can therefore be used also in patients with less severe lung disease. However, the diagnostic utility of TBB in the various clinical settings of pulmonary vasculitis has not been formally examined.
Case reports have demonstrated that radiologicallyguided TBB of gross parenchymal lesions can be effective at obtaining diagnostic material [6-9]. Furthermore, TBBs of tracheobronchial lesions have yielded positive results in several $[8,10]$ but not all reports $[7,10]$. Recent studies demonstrated that high-resolution computed tomography (HRCT) and bronchoalveolar lavage (BAL) can yield evidence of pulmonary involvement by WG in many patients who are only mildly symptomatic and essentially free of abnormal findings by conventional radiography [11, 12]. HRCT findings include small nodular lesions, septal and nonseptal lines, and low-attenuation infiltrates, most of which are below the detection threshold of conventional radiography. Together with abnormal BAL cell patterns, these findings suggest low-grade, mainly interstitial lung disease. The role of TBB in these patients is unresolved.

The present study was therefore carried out to examine the diagnostic efficacy of TBB in patients with ANCAassociated vasculitides and mild-to-moderate pulmonary involvement. Included in the study were patients with HRCT, BAL or clinical findings suggestive of pulmonary disease, but without gross lesions accessible by TBB under radiographical guidance. All patients had also 
undergone a detailed otolaryngological examination. Any suspicious lesions in the nasal cavity or the paranasal sinuses were biopsied and the number of positive upper respiratory tract biopsies was compared with that of TBB.

\section{Patients and methods}

\section{Patients}

Nineteen patients with active WG and six patients with CSS who had undergone TBB between January 1992 and June 1996 were retrieved by a chart review. The diagnosis of WG and CSS conformed with the 1990 American College of Rheumatology (ACR) criteria [13, 14] and the descriptive criteria of the Chapel Hill Conference of 1994 [15]. While the distinction between WG and microscopic polyangiitis is still a matter of debate, for the purposes of this study, patients with prominent involvement of the upper respiratory tract (including saddle-nose deformity) and sparing of the kidneys were considered to have WG rather than microscopic polyangiitis. Patients were subjected to a standardized diagnostic programme, including clinical work-up, otolaryngological ophthalmological and neurological referrals, chest radiography, pulmonary HRCT and cranial magnetic resonance imaging (MRI). The clinical status was categorized by the extended ELK score and the Disease Extent Index, as described elsewhere [16]. ANCA and ANCA subspecificities were measured using previously described methods [17]. All patients received fibreoptic bronchoscopy with BAL and TBB. Furthermore, biopsy was performed on any suspicious lesion in the upper respiratory tract as detected by direct inspection or MRI.

\section{Pulmonary function, HRCT}

Pulmonary function tests were carried out with a MasterLab unit (Jaeger, Wuerzburg, Germany). Pulmonary HRCT was performed with a Somatom Plus-S device (Siemens, Erlangen, Germany). Thin section radiographs (1 mm section thickness) were taken from the apex to the base of the lungs by a table feed of $10 \mathrm{~mm}$ with the patient lying in a dorsal position, and scans were reconstructed by means of a high spatial frequency reconstruction algorithm. The following findings were taken to indicate vasculitic or granulomatous pulmonary disease: nodules, septal and nonseptal lines; and ground-glass opacification.

\section{Bronchoscopy, BAL, TBB}

Fibreoptic bronchoscopy was performed under local anaesthesia with lidocaine after premedication with atropine and pethidine. BAL was performed in a single lung segment with $10 \times 20 \mathrm{~mL}$ sterile $0.9 \%$ saline. Cytocentrifuge preparations were prepared with a Shandon II cytocentrifuge (Shandon Products, Cheshire, UK). Slides were stained according to May-Grünwald-Giemsa and the cell differential was assessed by counting 500 cells. Aliquots of lavage material and tracheobronchial secretions were examined for conventional bacterial pathogens, acid-fast bacteria, Legionella species, Chlamydia species, Mycoplasma species, and Pneumocystis carinii. TBB was performed with a type FB-20C or FB-21C forceps from Olympus (Hamburg, Germany). At least two samples were taken from peripheral lung tissue, preferably from sites which were abnormal on HRCT. Furthermore, any

Table 1. - Clinical characteristics of patients with Wegener's granulomatosis

\begin{tabular}{|c|c|c|c|c|c|c|c|c|c|c|}
\hline $\begin{array}{l}\mathrm{Pt} \\
\text { No. }\end{array}$ & Sex & $\begin{array}{l}\text { Age } \\
\text { yrs }\end{array}$ & $\begin{array}{c}\text { Organ } \\
\text { involvement }\end{array}$ & $\begin{array}{l}\text { Histological } \\
\text { confirmation }\end{array}$ & $\begin{array}{l}\text { ANCA-titre } \\
\text { specificity }\end{array}$ & $\begin{array}{c}\text { ESR } \\
\mathrm{mm} \cdot \mathrm{h}^{-1}\end{array}$ & $\begin{array}{c}\text { CRP } \\
\mathrm{mg} \cdot \mathrm{dL}^{-1}\end{array}$ & $\begin{array}{c}\mathrm{VCI} \\
\% \text { pred }\end{array}$ & $\begin{array}{c}\mathrm{FEV}_{1} / \mathrm{VC} \\
\% \text { pred }\end{array}$ & $\begin{array}{l}\text { TL,CO } \\
\% \text { pred }\end{array}$ \\
\hline 1 & $\mathrm{M}$ & 57 & $\mathrm{E}, \mathrm{Ey}, \mathrm{L}, \mathrm{A}, \mathrm{B}, \mathrm{C}, \mathrm{P}$ & $\mathrm{L}$ & $1: 128$, PR3 & 68 & 4.3 & 94 & 82 & 100 \\
\hline \multirow[t]{2}{*}{2} & M & 52 & $\mathrm{E}, \mathrm{K}, \mathrm{L}, \mathrm{A}, \mathrm{L}, \mathrm{P}, \mathrm{B}$ & $\mathrm{E}$ & $1: 256$, PR3 & 50 & 1.2 & 95 & 86 & 109 \\
\hline & & & & $\mathrm{E}$ & $1: 128$, PR3 & 84 & 1.7 & 91 & 80 & 93 \\
\hline 3 & M & 65 & $\mathrm{E}, \mathrm{L}, \mathrm{K}, \mathrm{A}, \mathrm{B}$ & E, L & $1: 64$, PR3 & 90 & 14.1 & 106 & 79 & 93 \\
\hline 4 & M & 52 & $\mathrm{E}, \mathrm{L}, \mathrm{K}, \mathrm{Ey}, \mathrm{A}, \mathrm{B}$ & $\mathrm{K}$ & $1: 512, \mathrm{PR} 3$ & 35 & 4.4 & 93 & 78 & 97 \\
\hline 5 & M & 28 & $\mathrm{~L}, \mathrm{~A}, \mathrm{P}$ & $\mathrm{L}$ & $1: 256, \mathrm{PR} 3$ & 4 & 0.5 & 89 & 90 & ND \\
\hline \multirow[t]{2}{*}{6} & M & 46 & E, L, A, B & $\mathrm{E}$ & $1: 8$, PR3 & 46 & 1.0 & 99 & 67 & 85 \\
\hline & & & & $\mathrm{E}$ & $1: 2, \mathrm{PR} 3$ & 6 & 0.4 & 106 & 80 & 83 \\
\hline 7 & $\mathrm{~F}$ & 72 & $\mathrm{E}, \mathrm{L}, \mathrm{K}, \mathrm{A}, \mathrm{P}, \mathrm{S}, \mathrm{B}$ & $\mathrm{E}$ & $1: 32, \mathrm{PR} 3$ & 30 & 0.5 & 124 & 78 & 56 \\
\hline 8 & $\mathrm{~F}$ & 57 & E, L, K, Ey, L, A, P & $\mathrm{E}$ & $1: 256, \mathrm{PR} 3$ & 10 & 0.8 & 106 & 81 & 107 \\
\hline 9 & $\mathrm{~F}$ & 65 & $\mathrm{E}, \mathrm{L}, \mathrm{K}, \mathrm{A}, \mathrm{B}$ & $\mathrm{K}$ & 1:128, PR3 & 130 & 17.7 & 130 & 68 & 95 \\
\hline 10 & M & 57 & E, L, Ey, A, P, S, B & $\mathrm{E}$ & 1:1024, PR3 & 6 & 0.4 & 86 & 81 & 109 \\
\hline 11 & $\mathrm{~F}$ & 74 & $\mathrm{E}, \mathrm{L}, \mathrm{Ey}, \mathrm{P}, \mathrm{B}$ & $\mathrm{NA}$ & $1: 32, \mathrm{MPO}$ & 28 & 0.4 & 92 & 87 & 90 \\
\hline 12 & $\mathrm{~F}$ & 55 & E, L, K, Ey, A, S, C, B & $\mathrm{E}$ & $1: 256, \mathrm{PR} 3$ & 100 & 16.4 & 74 & $\mathrm{ND}$ & 104 \\
\hline 13 & $\mathrm{~F}$ & 56 & $\mathrm{E}, \mathrm{L}, \mathrm{K}, \mathrm{A}, \mathrm{B}$ & $\mathrm{L}$ & 1:2048, PR3 & 78 & 3.8 & $\mathrm{ND}$ & $\mathrm{ND}$ & $\mathrm{ND}$ \\
\hline 14 & $\mathrm{~F}$ & 68 & $\mathrm{E}, \mathrm{L}, \mathrm{B}$ & $\mathrm{E}$ & $\mathrm{ND}$ & 24 & 0.4 & 113 & 63 & 99 \\
\hline 15 & $\mathrm{~F}$ & 33 & $\mathrm{E}, \mathrm{L}, \mathrm{K}, \mathrm{S}, \mathrm{H}, \mathrm{A}, \mathrm{B}$ & $\mathrm{E}$ & $\mathrm{ND}$ & 72 & 1.3 & 75 & 74 & 107 \\
\hline 16 & $\mathrm{~F}$ & 7 & $\mathrm{E}, \mathrm{L}, \mathrm{K}, \mathrm{Ey}, \mathrm{A}, \mathrm{P}, \mathrm{B}$ & $\mathrm{E}$ & $1: 256$, PR3 & 80 & 0.5 & 113 & 75 & 110 \\
\hline 17 & M & 49 & $\mathrm{E}, \mathrm{L}, \mathrm{K}, \mathrm{Ey}, \mathrm{A}, \mathrm{S}, \mathrm{B}$ & $\mathrm{K}$ & $1: 128$, PR3 & 14 & 0.4 & 102 & 78 & 76 \\
\hline 18 & M & 52 & $\mathrm{E}, \mathrm{L}, \mathrm{K}, \mathrm{Ey}, \mathrm{A}, \mathrm{P}, \mathrm{B}$ & $\mathrm{Mu}$ & $1: 128$, PR3 & 110 & 11.4 & 146 & $\mathrm{ND}$ & ND \\
\hline 19 & $\mathrm{~F}$ & 43 & $\mathrm{E}, \mathrm{L}, \mathrm{K}, \mathrm{Ey}, \mathrm{S}, \mathrm{A}, \mathrm{C}, \mathrm{L}, \mathrm{E}$ & $\mathrm{E}$ & $1: 2, \mathrm{PR} 3$ & 50 & 0.4 & 92 & 90 & 77 \\
\hline
\end{tabular}

Pt: patient; ANCA: antineutrophil cytoplasmic antibody; ESR: erythrocyte sedimentation rate; CRP: c-reactive protein; \% pred: percentage of predicted value; VCI: inspiratory vital capacity; FEV1: forced expiratory volume in one second; VC: vital capacity; TL,CO: transfer factor of the lung for carbon monoxide; M: male; F: female; nD: not detected; E: ear/nose/throat; L: lung; K: kidney; Ey: eye; A: arthritis; P: peripheral nervous system; C: central nervous system; H: heart; Mu: muscle; S: skin; B: constitutional symptoms; PR3: proteinase 3; NA: not accomplished; MPO: myeloperoxidase. 
bronchoscopically visualized exophytic, ulcerative or stenotic tracheobronchial lesions were biopsied under direct vision.

\section{Histopathology}

Tissue specimens were fixed in $4 \%$ buffered formalin. Paraffin-embedded material was stained with haematoxylin and eosin. Step sections of each biopsy were analysed according to the ACR criteria [13, 14].

\section{Results}

Nineteen patients with active WG underwent TBB on 21 occasions. The organ involvement at the time of examination is presented in table 1. Abnormal HRCT findings suggestive of pulmonary parenchymal involvement by WG were found in 17 instances. An abnormal BAL cell differential in the absence of infection was found in 12 patients. This included elevation of lymphocytes to $18-74 \%$ or an elevation of neutrophils to $8-35 \%$.

TBB yielded alveolar tissue on 17 occasions (table 2). Only one specimen each from two patients showed histopathological changes consistent with WG. In one patient (No. 1), an alveolar tissue biopsy contained a histiocytic granulomatous lesion without necrosis or vasculitic changes. Concomitant HRCT and BAL findings were septal thickening and elevation of BAL lymphocytes to $51 \%$. In the other patient (No. 2), an extravascular necrotizing granuloma but no vasculitis was found. This patient had a

Table 2. - Pulmonary disease manifestations and biopsy results in patients with Wegener's granulomatosis

\begin{tabular}{lcccc}
\hline & \multicolumn{2}{c}{ Documentation of lung involvement } & \\
\cline { 2 - 3 } $\begin{array}{l}\text { Pt } \\
\text { No. }\end{array}$ & $\begin{array}{c}\text { Clinical, } \\
\text { Bronchoscopy }\end{array}$ & HRCT & BAL & TBB \\
\hline 1 & & & \\
2 & UB & GG, SI & LA & IG \\
& & N, SI & & IG \\
3 & UB & & LA & AG \\
4 & TG & & & AG \\
5 & TG & GG & & AG, NSLT \\
6 & BS & & LA & AG \\
& & N & & NS \\
7 & & SI & LA & SGC \\
8 & & SI & NA & NS \\
9 & & GG & NA & NS \\
10 & & N, SI & & NS \\
11 & & GG, N & LA & NS \\
12 & & GG & & NS \\
13 & & N & & NS \\
14 & & N, SI & & NS \\
15 & & SI & NA & NS \\
16 & & GG, N & LA & NS \\
17 & & N & LA & NS \\
18 & & & LA & NS \\
19 & & GG & LA & NS \\
\hline
\end{tabular}

Pt: patient; HRCT: high-resolution computed tomography; BAL: bronchoalveolar lavage; TBB: transbronchial biopsy; UB: ulcerative bronchitis; TG: tracheal granuloma; BS: bronchial stenosis; SI: septal infiltration; GG: ground-glass; N: nodules; LA: lymphocytic alveolitis; NA: neutrophilic alveolitis; IG: interstitial granuloma; AG: airway granuloma; NSLT: nonspecific lung tissue; NS: nonspecific; SGC: scattered giant cells. normal chest radiograph but scattered ground-glass opacification and septal thickening on HRCT. Both of these individuals fulfilled the ACR criteria for WG and were proteinase 3 (PR3)-ANCA positive, so that the granulomatous lesions were considered to support the clinical diagnosis. The biopsy of another patient (No. 7) showed scattered interstitial multinucleated giant cells without granuloma, vasculitis or necrosis. This pattern was not considered sufficiently specific to support the diagnosis. The remaining patients had nonspecific histopathological changes of alveolar tissue, including infiltration with mononuclear cells and mild focal fibrosis, which were insufficient to support specific diagnosis.

Bronchoscopy revealed exophytic, ulcerative or stenotic airway lesions in five WG patients and lesional biopsy invariably showed changes consistent with WG (table 2). All of these patients had persistent cough with or without haemoptysis. Two patients had granulomatous, partly exophytic lesions in the trachea, two had ulcerating bronchial lesions and one had segmental stenosis of an upper lobe bronchus. Biopsies from these lesions showed either nec-rotizing or non-necrotizing granuloma without vasculitic changes.

Taken together, only seven of 21 biopsies from the lower respiratory tract disclosed histopathological changes supporting the diagnosis of WG. The diagnostic yield of biopsies from the upper respiratory tract was definitely higher. Clinical examination and MRI showed nasal and paranasal abnormalities in 19 instances and biopsy from these sites yielded a histopathology supporting the diagnosis in 13 patients (table 1 ).

The diagnostic yield of TBB was somewhat higher in the six patients with CSS. All of these had active pulmonary disease (table 3 ) as evidenced by asthma in five patients, an abnormal HRCT in two patients (ground-glass opacification in one and reversible segmental atelectasis in the other) and an abnormal BAL in four (elevation of eosinophils or lymphocytes in two patients each). Patient No. 22 was free of asthma, but had a history of asthma over several years, which subsided when he entered the vasculitic phase of disease. Other organ manifestations of the six CSS patients are presented in table 4. TBB yielded alveolar tissue in all six patients. In none of these biopsies were vasculitis or granulomata found. Four of six patients showed sparse interstitial infiltration with eosinophils in specimens containing small vessels and were thus consistent with the ACR criteria for CSS (table 3). The remaining

Table 3. - Pulmonary disease manifestations and biopsy results in patients with Churg-Strauss syndrome

\begin{tabular}{lcccc}
\hline & \multicolumn{2}{c}{ Documentation of lung involvement } & \\
\cline { 2 - 3 } $\mathrm{Pt}$ & $\begin{array}{c}\text { Clinical, } \\
\text { bonchoscopy }\end{array}$ & HRCT & BAL & TBB \\
No. & Asthma & \multirow{2}{*}{ GG } & LA & NS \\
\hline 20 & Asthma & & LA & EE \\
21 & & & & NS \\
22 & Asthma & SA & EA & EE \\
23 & Asthma & & EA & EE \\
24 & Asthma & & EA \\
25 & &
\end{tabular}

SA: segmental atelectasis; EA: eosinophilic alveolitis; EE: extravascular eosinophils. For further definitions, see legend to table 2. 
Table 4. - Clinical characteristics of patients with Churg-Strauss syndrome.

\begin{tabular}{|c|c|c|c|c|c|c|c|c|c|c|}
\hline $\begin{array}{l}\mathrm{Pt} \\
\text { No. }\end{array}$ & Sex & $\begin{array}{l}\text { Age } \\
\text { yrs }\end{array}$ & $\begin{array}{c}\text { Organ } \\
\text { involvement }\end{array}$ & $\begin{array}{l}\text { Histological } \\
\text { confirmation }\end{array}$ & $\begin{array}{l}\text { ANCA-titre } \\
\text { specificity }\end{array}$ & $\begin{array}{l}\mathrm{ESR} \\
\mathrm{mm} \cdot \mathrm{h}^{-1}\end{array}$ & $\begin{array}{c}\mathrm{CRP} \\
\mathrm{mg} \cdot \mathrm{dL}^{-1}\end{array}$ & $\begin{array}{c}\mathrm{VCI} \\
\% \text { pred }\end{array}$ & $\begin{array}{c}\mathrm{FEV}_{1} / \mathrm{VC} \\
\% \text { pred }\end{array}$ & $\begin{array}{l}T \mathrm{~L}, \mathrm{CO} \\
\% \text { pred }\end{array}$ \\
\hline 20 & $\mathrm{~F}$ & 67 & E, L, K, S, P, B & E, K & ND & 16 & 0.4 & 111 & 74 & 88 \\
\hline 21 & $\mathrm{~F}$ & 37 & $\mathrm{E}, \mathrm{L}, \mathrm{K}, \mathrm{A}, \mathrm{S}, \mathrm{P}, \mathrm{B}$ & $\mathrm{E}$ & 1:32, PR3 & 14 & 0.4 & 112 & 78 & 78 \\
\hline 22 & $\mathrm{~F}$ & 48 & E, L, S, A, H, B & $\mathrm{E}$ & ND & 12 & 0.4 & 100 & 76 & 79 \\
\hline 23 & $\mathrm{~F}$ & 57 & $\mathrm{E}, \mathrm{L}, \mathrm{A}, \mathrm{S}, \mathrm{H}, \mathrm{A}, \mathrm{B}$ & $\mathrm{E}$ & ND & 44 & 0.4 & 93 & 64 & 95 \\
\hline 24 & $\mathrm{M}$ & 49 & E, L, A, P, M, S, B & $\mathrm{E}, \mathrm{M}$ & ND & 22 & 0.4 & 70 & 58 & 67 \\
\hline 25 & M & 38 & $\mathrm{E}, \mathrm{L}, \mathrm{K}, \mathrm{H}, \mathrm{C}, \mathrm{A}, \mathrm{B}$ & $\mathrm{K}$ & $\mathrm{ND}$ & 35 & 1.6 & 69 & 87 & 82 \\
\hline
\end{tabular}

For definitions, see legend to table 1.

two patients had only nonspecific changes, including infiltration with mononuclear cells and focal interstitial fibrosis, which did not support the diagnosis. On the other hand, otolaryngological examination and cranial MRI revealed nasal and paranasal abnormalities in five patients. Biopsies from these sites consistently revealed extravascular eosinophils in specimens containing small vessels, thereby complying with the ACR criteria for a positive histopathology.

\section{Discussion}

A wide spectrum of tissue changes is known to occur in WG, and histopathological diagnosis, like clinical diagnosis, relies on a combination of findings rather than on any single feature $[1,18,19]$. The main criteria for $\mathrm{WG}$ are necrotizing vasculitis involving predominantly small arteries and veins, granulomata consisting of histiocytes and multinucleated giant cells, and "geographic" necrosis [1, $18,19]$. From the histopathological point of view, the presence of all three of these confers the highest degree of diagnostic certainty [18, 19], but this situation is fairly uncommon. In a previous study of 126 biopsy specimens from the head and neck regions in WG patients, only $16 \%$ showed this triad whereas the majority of specimens fulfilled less than three criteria and did not therefore permit a definitive diagnosis solely on histopathological grounds [19]. The value of such biopsies depends very much on the clinical context. In a setting highly suggestive of WG, the presence of only one or two of the main histopathological criteria can give valuable support to the diagnosis, while in the context of an ambiguous clinical picture they are of little help. Combinations of histopathological and clinical findings for diagnosis of WG have been proposed by several authors $[1,18,19]$, but only the 1990 ACR criteria have been formally evaluated [13].

Although these are classification rather than diagnostic criteria, they provided the framework for our interpretation of the present biopsy results. The minimum requirement for a tissue specimen to support the diagnosis of WG was the presence of granuloma or vasculitis in association with a clinical picture complying with the ACR criteria for WG.

The TBB results of the present WG cohort agree with previous studies with respect to the limited information contained in small biopsy specimens $[18,19]$. In no case was the complete histopathological picture of WG found which would have permitted a definitive diagnosis, but positive specimens contained only necrotizing or nonnecrotizing granuloma. The second main finding was the low diagnostic yield of peripheral lung tissue obtained by TBB. Only two of 17 specimens containing alveolar tissue showed granulomata, which in the context of an appropriate clinical picture led to the diagnosis of WG. Another patient had only scattered multinucleated giant cells within alveolar septa. This is also a fairly common feature in biopsies from the upper respiratory tract in WG patients $[1,9,19]$, but it is not specific enough to support any particular diagnosis. The remaining alveolar tissue specimens showed nonspecific inflammatory and cicatricial changes, which have been termed the inflammatory background of WG [9].

We see two reasons for the low diagnostic yield of alveolar tissue in these patients. Firstly, studies of open lung biopsies and necropsy material have demonstrated a distinctly focal distribution of granulomatous and vasculitic lesions within the lung $[1,4,18]$. Conceivably, this entails a large sampling error if no attempt is made to obtain lesional tissue. Secondly, the distinction between active inflammatory lesions and cicatricial changes is difficult to make by HRCT and carries the risk of misclassifying fibrotic residue as active inflammation. Our ongoing longitudinal study of the effect of immunosuppressive treatment on pulmonary findings has revealed that most (but not all) of the lesions detected by HRCT in this study receded during effective treatment. This suggests that in the majority of the present cases such lesions reflected active disease, although some contamination by cicatricial changes must be taken into account. Clearly, open lung biopsy would resolve this problem, but the preponderance of the risks over the presumed benefits of surgical biopsy in these patients with low-grade pulmonary disease militates against this fairly aggressive approach. We conclude, therefore, that TBB of peripheral lung tissue is a viable option in the event of parenchymal lesions which are large enough to be biopsied under radiographical guidance, but not if it is carried out in a blind fashion.

On the other hand, ulcerative, exophytic or stenotic tracheobronchial lesions with signs of active inflammation were found in five of $21 \mathrm{WG}$ patients, and biopsy from these sites invariably yielded a diagnostically helpful histopathology. The low frequency of these lesions in the present series compares well with that in the compilation of WG cases of CoRDIER et al. [5], who found 20 focal airway lesions in 74 patients, whereas the frequency was 27 out of 51 in the study of Daum et al. [10]. The essence of these three studies is that bronchoscopy produces an appreciable number of focal inflammatory lesions with a high yield of positive biopsies in WG patients with clinical evidence of lower airway disease.

Given the fact that the nasal cavity and the paranasal sinuses are affected in the majority of WG patients [3], all of the present patients received a detailed otolaryngo- 
logical examination including biopsy of any suspicious lesion. Using this approach, a positive upper respiratory tract biopsy was obtained in 13 patients as opposed to only seven positive biopsies from the lower respiratory tract. If one considers that nasal and paranasal biopsy sites are generally easier to approach and allow sampling at lower risk, these sites carry a clear advantage over the lower respiratory tract.

CSS has a number of features in common with WG. Both are small vessel vasculitides of unclear aetiology with universal involvement of the respiratory tract, at least at some point during course, and many similarities exist in the pattern of organ involvement beyond the respiratory tract [20, 21]. Histopathologically, the characteristic lesions of CSS are granulomatous or nongranulomatous vasculitis and extravascular eosinophilic granuloma. The combination of these in a single specimen is taken to be diagnostic [22-24]. Reportedly, in CSS too the complete histopathological picture is the exception rather than the rule [22-24]. For the purposes of this study, the minimum requirement for a biopsy to support the diagnosis of CSS was the presence of vasculitis, granuloma or, in accordance with the ACR criteria for CSS, tissue eosinophilia in a specimen containing a small vessel. These findings needed to be accompanied by a clinical picture complying with the ACR criteria for CSS [14].

In the present cohort of CSS patients, TBB of alveolar tissue yielded a positive histopathology in four out of six patients. All six CSS patients also had active upper respiratory tract disease and five yielded a positive histopathology by nasal or paranasal biopsy. The small number of observations precludes any definitive conclusions, but suggests that TBB of alveolar tissue has a higher diagnostic yield in CSS than in WG. Furthermore, biopsies from the upper and the lower respiratory tracts seem to be comparable in the number of positive results they produce in CSS. These conclusions are subject to a caveat with respect to the efficacy of the ACR criteria for CSS, which require a positive histopathology to show merely tissue eosinophilia in specimens containing an arterial or venous vessel, but neither vasculitis nor granuloma is needed [14]. Reportedly, these criteria had a specificity for CSS of more than $99 \%$, but the database for this evaluation included only 20 patients with this diagnosis [14]. Hence, caution in the use of this particular set of criteria is called for until more extensive testing has been completed.

Taken together, the findings of this study demonstrate that transbronchial biopsies of alveolar tissue have a low yield in Wegener's granulomatosis patients presenting with only high-resolution computed tomography or bronchoalveolar lavage abnormalities but no gross parenchymal lesions. On the other hand, transbronchial biopsy is an effective technique if gross lesions are approached under radiographical guidance or if ulcerative, exophytic or stenotic tracheobronchial lesions are biopsied under direct vision. Given the high prevalence of upper respiratory tract involvement in Wegener's granulomatosis and the generally easy access to these sites, we therefore propose that the upper rather than the lower respiratory tract be the biopsy site of first choice in Wegener's granulomatosis patients. Our results further suggest that the upper and the lower respiratory tracts yield comparable numbers of positive biopsies in Churg-Strauss syndrome, but this conclusion is based on only a small number of observations.
Finally, none of the positive biopsies in either Wegener's granulomatosis or Churg-Strauss syndrome allowed a definitive diagnosis based solely on histopathology, which underlines the importance of a close co-operation between the clinician and the pathologist to fully exploit the diagnostic information contained in small biopsy specimens.

\section{References}

1. Travis WD, Hoffman GS, Leavitt RY, Pass HI, Fauci AS. Surgical pathology of the lung in Wegener's granulomatosis. Am J Surg Pathol 1991; 15: 315-333.

2. Gross WL, Csernok E. Immunodiagnostic and pathophysiologic aspects of antineutrophil cytoplasmic antibodies in vasculitis. Curr Op Rheumatol 1995; 7: 11-19.

3. Hoffman GS, Kerr GS, Leavitt RY, et al. Wegener's granulomatosis: an analysis of 158 patients. Ann Int Med 1992; 116: 488-498.

4. Gaudin PB, Askin FB, Falk RJ, Jennette JC. The pathologic spectrum of pulmonary lesions in patients with anti-neutrophil cytoplasmic autoantibodies specific for anti-proteinase 3 and myeloperoxidase. Am J Clin Pathol 1995; 104: 7-16.

5. Cordier J-F, Valeyre D, Guillevin L, Loire R, Brechot J-M. Pulmonary Wegener's granulomatosis. a clinical and imaging study of 77 cases. Chest 1990; 97: 906-912.

6. Delp Givens C, Newman JH, McCurley TL. Diagnosis of Wegener's granulomatosis by transbronchial biopsy. Chest 1985; 88: 794-796.

7. Ackerman Z, Orbach H, Burstein M, Breuer R. Transbronchial biopsies in Wegener's granulomatosis. Ann Int Med 1986; 105: 801-802.

8. Yuasa K, Tokitsu M, Goto H, Kato H, Shimada K. Wegener's granulomatosis: diagnosis by transbronchial lung biopsy, evaluation by gallium scintigraphy and treatment with sulfamethoxazole/trimethoprim. Am J Med 1988; 84: $371-372$.

9. Lombard CM, Duncan SR, Rizk NW, Colby TV. The diagnosis of Wegener's granulomatosis from transbronchial biopsy specimens. Hum Pathol 1990; 21: 838-842.

10. Daum TE, Specks U, Colby TV, et al. Tracheobronchial involvement in Wegener's granulomatosis. Am J Respir Crit Care Med 1995; 151: 522-526.

11. Schubert F, Muhle C, Schnabel A, et al. High-resolution computed tomography of the lung in Wegener's granulomatosis. RoFo Fortschr Geb Rontgenstr Neuen Bildgeb Verfahr 1994; 161: 19-24.

12. Schnabel A, Reuter M, Richter C, Gross WL. Bronchoalveolar lavage cytology in subacute Wegener's granulomatosis. Sarcoidosis 1996; 13: 272 (abstract).

13. Leavitt RY, Fauci AS, Bloch DA, et al. The American College of Rheumatology 1990 Criteria for the classification of Wegener's granulomatosis. Arthritis Rheum 1990; 33: 1101-1107.

14. Masi AT, Hunder GG, Lie JT, et al. The American College of Rheumatology 1990 Criteria for the Classification of Churg-Strauss syndrome (allergic granulomatosis and angiitis). Arthritis Rheum 1990; 33: 1094-1100.

15. Jennette JC, Falk R, Andrassy K, et al. Nomenclature of systemic vasculitides. Proposal of an international conference. Arthritis Rheum 1994; 37: 187-192.

16. Reinhold-Keller E, Kekow J, Schnabel A, et al. Influence of disease manifestation and antineutrophil cytoplasmic antibody titer in the response to pulse cyclophosphamide therapy in patients with Wegener's granulomatosis. Arthritis Rheum 1994; 37: 919-924. 
17. Nölle B, Specks U, Lüdemann J, Rohrbach MS, De-Remee RA, Gross WL. Anticytoplasmic autoantibodies: Their immunodiagnostic value in Wegener's granulomatosis. Ann Intern Med 1989; 111: 28-40.

18. Mark EJ, Matsubara O, Tan-Liu NS, Fienberg R The pulmonary biopsy in the early diagnosis of Wegener's (pathergic) granulomatosis - a study based on 35 open lung biopsies. Hum Pathol 1988; 19: 1065-1071.

19. Devaney KO, Travis WD, Hoffman GS, Leavitt RY, Lebovics RS, Fauci AS. Interpretation of head and neck biopsies in Wegener's granulomatosis. Am J Surg Pathol 1990; 14: 555-564.

20. Specks U, DeRemee RA. Granulomatous vasculitis: Wegener's granulomatosis and Churg-Strauss syndrome. Rheum Dis Clin North Am 1990; 16: 377-397.
21. Klinkenborg A, Reinhold-Keller E, Csernok E, Gross WL. Churg-Strauss syndrome as a distinctive ANCA- associated vasculitis. Sarcoidosis 1996; 13: 270 (abstract).

22. Lanham JG, Elkon KB, Pusey CD, Hughes GR: Systemic vasculitis with asthma and eosinophilia: a clinical approach to the Churg-Strauss syndrome. Medicine 1984; 63: 65-81.

23. Chumbley LC, Harrison EG, DeRemee RA. Allergic gran-ulomatosis and angiitis (Churg-Strauss syndrome) report and analysis of 30 cases. Mayo Clin Proc 1977; 52: 477-484.

24. Lie JT. The classification of vasculitis and a reappraisal of allergic granulomatosis and angiitis (Churg-Strauss syndrome). Mt Sinai J Med 1986; 53: 429-439. 